\title{
Stable rock walls in a large open stope at Sunrise Dam Gold Mine
}

\author{
L.A. Nienaber AngloGold Ashanti Limited, Australia
}

S. Tombs AngloGold Ashanti Limited, Australia

\begin{abstract}
In the Cosmo orebody the complexity and quantity of the payable lodes necessitated the use of a bulk mining method. This method has undergone several changes since the conceptual stage. It highlights the need for flexibility in mine designs and the ability to assess the impact on the rock mass conditions. The concept of design-as-you-mine describes this in a crude way. Over time a broader experience base develops and this allows for optimal assessment of the designs. With each design iteration, the knowledge and understanding of the Cosmo rock mass increased. The design validation using the trial stope resulted in the successful extraction of the first $165 \mathrm{kt}$ primary stope.
\end{abstract}

\section{Introduction}

Sunrise Dam Gold Mine (SDGM), 100\% owned by AngloGold Ashanti, is the single largest gold deposit in the Laverton Tectonic Zone of the Eastern Goldfields Province, Western Australia. The mine lies on the north-eastern shore of Lake Carey in the northern goldfields of Western Australia. It is located approximately $770 \mathrm{~km} \mathrm{NE}$ of Perth, $220 \mathrm{~km} \mathrm{NNE}$ of Kalgoorlie and $55 \mathrm{~km}$ south of the township of Laverton (Figure 1).

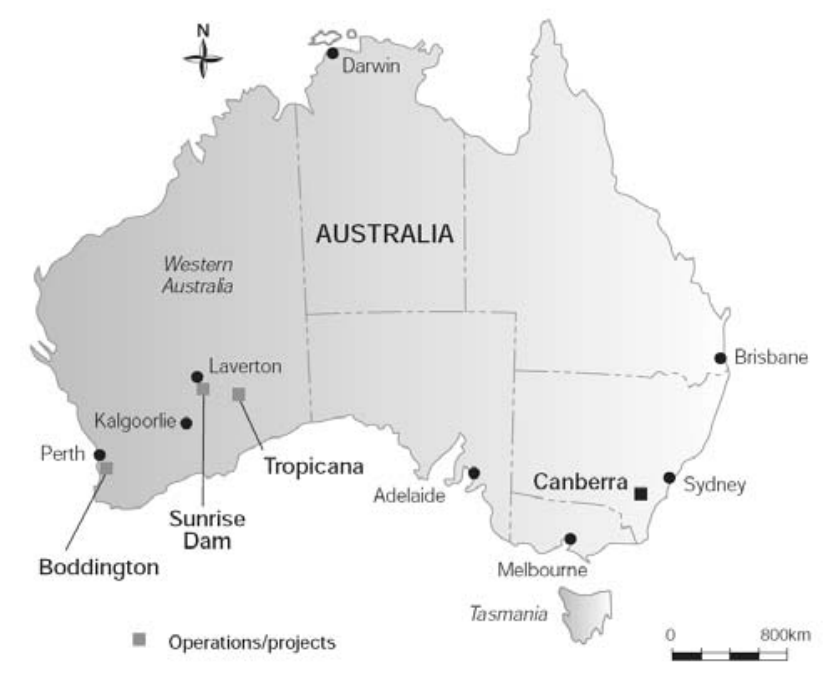

Figure 1 Locality map of SDGM (Boddington interest sold early 2009)

The underground operation started as a feasibility study with the first decline in October 2003. Following the completion of the feasibility study by the end of 2007 it became fully operational. At SDGM each of the complex orebodies has their unique geotechnical challenges. This paper describes the geotechnical and mining experiences during the design and extraction of the Cosmo orebody as geological interpretation of the ore structures has evolved.

\section{Geological setting}

SDGM is contained within the NW-SE-trending (Mine North reference) regional structural domain known as the Laverton Tectonic Zone (Figure 2), as described by Nugus and Biggam (2007). The Cosmo orebody has its own unique geometrical details, which has been summarised within this paper. 


\subsection{Structure}

A series of closely spaced, predominantly NW striking shears developed proximal to contacts between dolerite-andesite-felsic porphyry. Up to eight individual, discrete shear zones have been mapped out in a $10 \mathrm{~m}$ cross sectional area. Structures are offset by shallow west dipping and steep N-S striking faults and deflect around felsic intrusive porphyries. Stock work-like pipe zones exist with NW dominant trending individual faults and linked by N-S steep and flat faults.

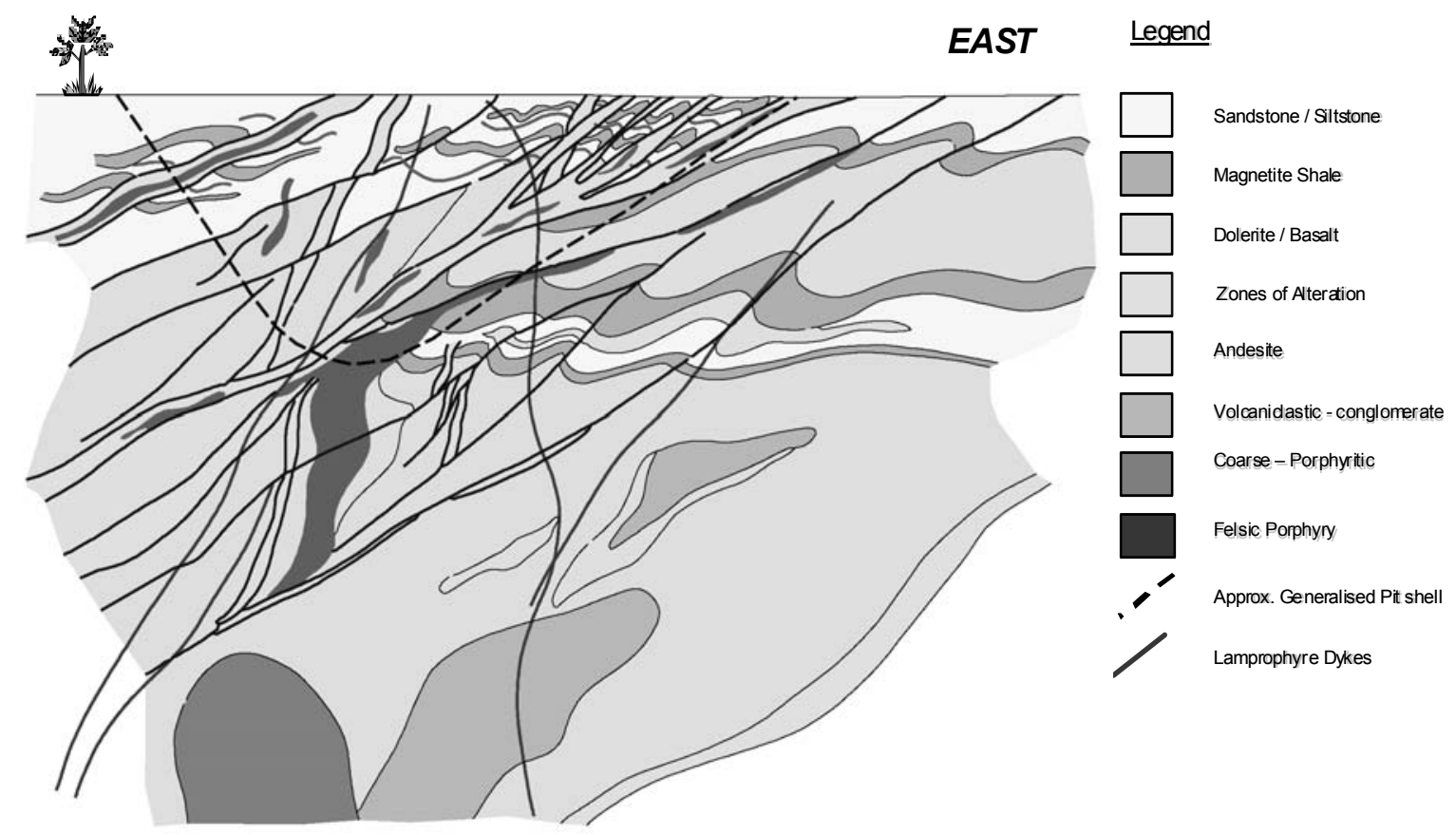

Figure 2 Schematic cross section of the geology at Sunrise Dam, illustrating the complex interplay between structures and stratigraphy within the mine area

\subsection{Lode orientation and geometry}

Mineralisation is hosted in sulphide-rich breccia veins within the andesitic units or as sulphide-silica veinlets within the porphyry. Within available exposures underground, mineralised zones are almost always $60-80^{\circ} \mathrm{W}$ dipping, though the trend varies to either NW or NNE. This is also determined from the structural data obtained from drill core. (Some evidence indicates that the ore zones may be folded although this is spurious.) The west dipping lodes do appear to be transected by flat dipping, auriferous faults similar to those within the Western Shear Zone. A simplified sectional geometry of the Cosmo orebody is shown in Figure 3. 


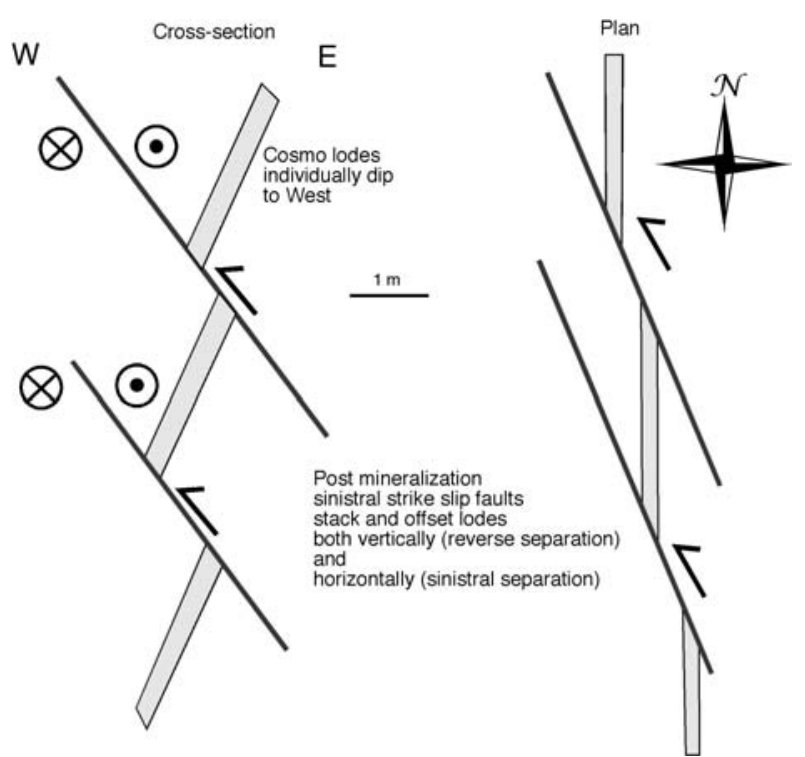

Figure 3 Sectional geometry of the Cosmo orebody

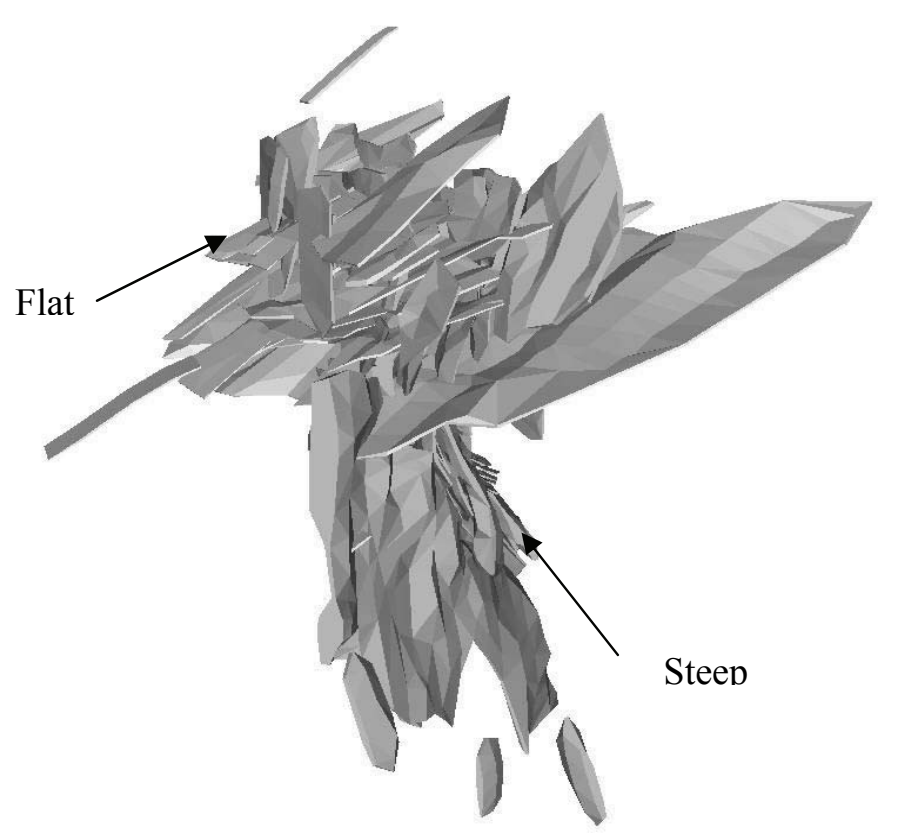

Figure 4 Oblique view north showing the flat and steep westerly dipping structures in the Cosmo orebody

From the limited exposures the geometry of the individual ore zones was interpreted to be in the order of greater than $40 \mathrm{~m}$ strike, by 0.5 to $2 \mathrm{~m}$ (wide), by 15 to $40 \mathrm{~m}$ dipping west. Underground exposures and detailed mapping resulted in a much better understanding of the structural defects. The west dipping mineralised zones described above were classified as flat and steep dipping structures (Figure 4). 


\section{Cosmo orebody geotechnical overview}

\subsection{Rock mass characteristics}

Rock mass data collected from drill core and underground mapping have been used in the calculation of Q values (Cowan, 2006; Hamman, 2007a, 2007b; Brockman, 2008a, 2008b and 2009) and is summarised in Table 1 . The vast amount of rock mass data collected and statistically analysed has resulted in a thorough characterisation of the Cosmo rock mass. Laboratory test results for the major rock types are shown in Table 2. The optimised rock mass classification (Table 3) used by Brockman (2008b) in the pre-mining kinematic analyses correlates with the previous classifications.

Table 1 Rock mass quality comparison for the Cosmo orebody

\begin{tabular}{llllllll}
\hline & $\begin{array}{l}\text { Cowan } \\
(\mathbf{2 0 0 6})\end{array}$ & $\begin{array}{l}\text { Hamman } \\
(\mathbf{2 0 0 7 a , 2 0 0 7 b )}\end{array}$ & \multicolumn{5}{c}{$\begin{array}{c}\text { Brockman } \\
(\mathbf{2 0 0 8 a}, \mathbf{2 0 0 8 b}, \mathbf{2 0 0 9})\end{array}$} \\
\hline Rock mass quality designation (RQD) & 87.0 & 95 & 95 & 60 & 90 & 80 & 90.0 \\
Joint set number (Jn) & 6.0 & 9 & 9 & 9 & 15 & 9 & 12.0 \\
Joint roughness number (Jr) & 1.5 & 3 & 1.5 & 2 & 3 & 1.5 & 3.0 \\
Joint alteration number (Ja) & 1.0 & 1 & 1 & 1 & 1 & 1 & 1.0 \\
Joint water reduction (Jw) & 1.0 & 1 & 1 & 1 & 1 & 1 & 1.0 \\
Stress reduction factor (SRF) & 2.5 & 5 & 2.5 & 2.5 & 2.5 & 2.5 & 2.5 \\
Structural characteristics (RQD/Jn): & 14.5 & 10.6 & 10.6 & 6.7 & 6.0 & 8.9 & 7.5 \\
Frictional characteristics (Jr/Ja): & 1.5 & 3.0 & 1.5 & 2.0 & 3.0 & 1.5 & 3.0 \\
Hydrological and stress (Jw/SRF): & 0.4 & 0.2 & 0.4 & 0.4 & 0.4 & 0.4 & 0.4 \\
\hline Rock Mass Quality (Q, Barton, 1974): & $\mathbf{8 . 7}$ & $\mathbf{6 . 3}$ & $\mathbf{6 . 3}$ & $\mathbf{5 . 3}$ & $\mathbf{7 . 2}$ & $\mathbf{5 . 3}$ & $\mathbf{9 . 0}$ \\
Modified Quality Index (Q'): & $\mathbf{2 1 . 8}$ & $\mathbf{3 1 . 7}$ & $\mathbf{1 5 . 8}$ & $\mathbf{1 3 . 3}$ & $\mathbf{1 8 . 0}$ & $\mathbf{1 3 . 3}$ & $\mathbf{2 2 . 5}$ \\
Rock mass quality is fair, Q $=4$ to 10 & & & & & & & \\
\hline
\end{tabular}

Table 2 Test results for the different rock types (UCS - MPa, E - GPa)

\begin{tabular}{lllllll}
\hline $\begin{array}{l}\text { Lithology } \\
\text { Rock Code }\end{array}$ & BIF & $\begin{array}{l}\text { Dolerite } \\
\text { ACI }\end{array}$ & $\begin{array}{l}\text { Basalt } \\
\text { AB }\end{array}$ & $\begin{array}{l}\text { Andesite } \\
\text { AIA }\end{array}$ & $\begin{array}{l}\text { Volcanics } \\
\text { AFS }\end{array}$ & $\begin{array}{l}\text { Porphyry } \\
\text { AG }\end{array}$ \\
\hline UCS $_{\text {Ave }}$ & 123 & 81 & 164 & 126 & 106 & 85 \\
UCS $_{\text {Min }}$ & 56 & 55 & 146 & 102 & 50 & 41 \\
UCS $_{\text {Max }}$ & 242 & 96 & 181 & 159 & 244 & 167 \\
$E_{\mathrm{t}}$ & 67 & 47 & 75 & 40 & 65 & 92 \\
$v$ & 0.31 & 0.3 & 0.22 & 0.31 & 0.25 & 0.2 \\
\hline
\end{tabular}




\section{Table 3 Cosmo rock mass classification}

\begin{tabular}{l|l}
\hline Geology & Andesite and volcanic-clastic rocks hosting moderate alteration \\
Rock alteration & Moderate \\
Q & $3.5-15$ \\
Domain & Moderately blocky (RQD $\sim 80, \mathrm{Jn}=9-15)$ \\
Joint sets & Set 1: 74/228 Set 2: $42 / 209 \quad$ Set 3: $69 / 046 \quad$ Set 4: 89/125 \\
Overall joint conditions & Joints vary from planar to undulating rough $(\mathrm{Jc}=1.5-3)$ \\
Joint alteration & Alteration on jointing is rare, surface staining only $(\mathrm{Ja}=1)$ \\
Water conditions & Dry/minor inflow $(\mathrm{JW}=1) \quad$ Joint length $(\mathrm{m}) \quad \sim 5 \mathrm{~m}$ \\
Joint penetration expected $(\mathbf{m})$ & $\sim 5 \mathrm{~m} \quad$ Low stress (SRF $=2.5)$ \\
Stress reduction factor & Overall rock mass is fair \\
Comments &
\end{tabular}

Properties deemed representative of the Cosmo rock mass that are used in the rock mass classification to calculate the Hoek-Brown and Mohr-Coulomb strength criterions for the rock mass, have been summarised in Table 4 (Hamman, 2007c). These values are typically used in numerical modelling such as MAP3D and PHASE 2.

\section{Table 4 Hoek-Brown classification}

\begin{tabular}{lll}
\hline Rock Mass Properties & Unit & Value \\
\hline Uniaxial compressive strength (UCS) & $\sigma_{\mathrm{ci}}$ & $120 \mathrm{MPa}$ \\
Geological strength index (GSI) & $\mathrm{GSI}$ & 70 \\
Material constant & $\mathrm{m}_{\mathrm{i}}$ & 22 \\
Disturbance factor & $\mathrm{D}$ & 0.4 \\
Modulus of elasticity & $\mathrm{E}_{\mathrm{m}}$ & $80 \mathrm{GPa}$ \\
\hline
\end{tabular}

Strain burst proneness tests evaluates the relative brittleness of the rock, to project its potential to interact with high stresses, which result in mining seismicity or rockbursts (Bamford, 2007). The suite of rocks tested tended to behave in a ductile, non-violent manner.

\subsection{Stress regime}

Several stress measurements have been completed since the start of the open pit mine. The Acoustic Emission (Villaescusa et al., 2006) and Hollow Inclusion (Litterbach, 2008) test results from various sites around the mine have been analysed, and a stress versus depth relationship was derived by Peter O'Bryan and Associates (2008):

$$
\begin{aligned}
& \sigma_{1}=0.0663 \times \text { depth }+10 \mathrm{MPa} \quad \text { dip and plunge: } 06^{\circ} / 155^{\circ} \\
& \sigma_{2}=0.0221 \times \text { depth }+14 \mathrm{MPa} 20^{\circ} / 063^{\circ} \\
& \sigma_{3}=0.0299 \times \text { depth } \quad 69^{\circ} / 260^{\circ}
\end{aligned}
$$

Extraction of the Cosmo orebody range in depth below surface from $483 \mathrm{~m}$ to $563 \mathrm{~m}$, and based on the relationship (1) the major principal stress value (sub-horizontal) increase slightly from $42 \mathrm{MPa}$ to $47 \mathrm{MPa}$. The major rock types in the Cosmo are Andesite and Volcaniclastics (Table 3) with average UCS values of 126 and $106 \mathrm{MPa}$ (Table 2). Stress values calculated above are approaching 50\% of the individual intact rock 
strength. Damage observed at a depth of $563 \mathrm{~m}$ below surface (COS 1832 level) along the pillar edge has indicated that the onset of stress concentration was occurring (Nienaber, 2009).

\subsection{Seismicity}

No strain bursting or rock noise has been observed to date. A very low activity has been observed (ISSP, $2009)$, even with two of the Cosmo primary stopes already extracted $\left( \pm 120,000 \mathrm{~m}^{3}\right)$. This was attributed to the low strain burst index calculated by Bamford (2007) and summarised by Hamman (2007d) in Figure 5. However, as mining progress deeper and the extraction increase, it is expected that seismic activity will increase.

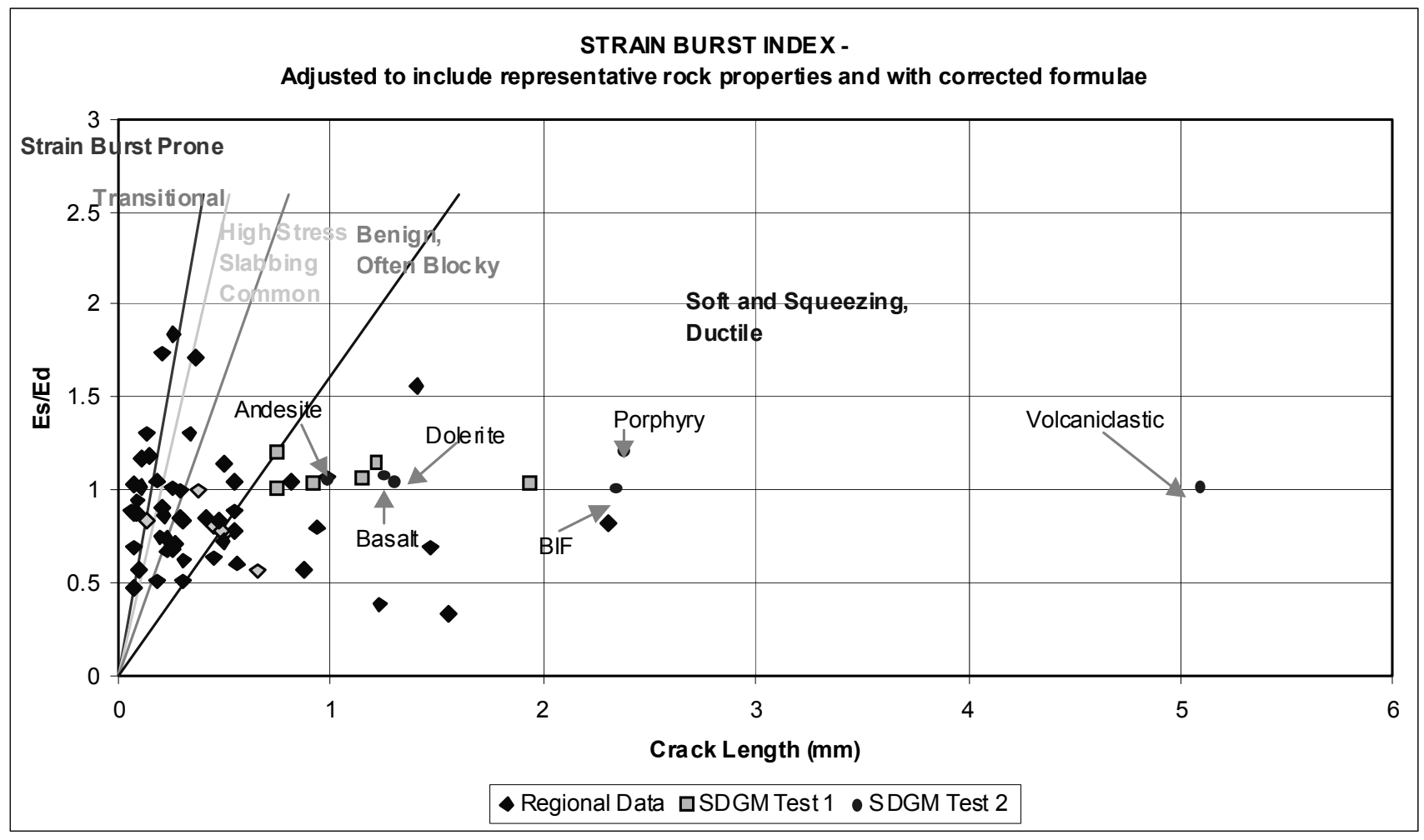

Figure 5 Strainburst index for the rock types at SDGM, indicating a low risk for violent rock failure

\section{$4 \quad$ Excavation design and support}

\subsection{Excavation layout}

Bulk stoping of the Cosmo orebody necessitated the design of primary and secondary stopes. The initial designs of $8 \mathrm{~m}$ primary and $12 \mathrm{~m}$ secondary (8P12S) (Figure 6) with a $20 \mathrm{~m}$ lift was compared to $20 \mathrm{~m}$ primary and $20 \mathrm{~m}$ secondary (20P20S) (Figure 7) at $50 \mathrm{~m}$ and $75 \mathrm{~m}$ lifts (Hamman, 2007c; Guilfoyle, 2007a, 2007b, 2007c). Development requirements as well as possible dilution have also been analysed. Further analysis (Nienaber, 2008a) has compared various stopes sizes with small differences observed in stress interactions when the 20P20S was compared to the 25P30S stopes. 


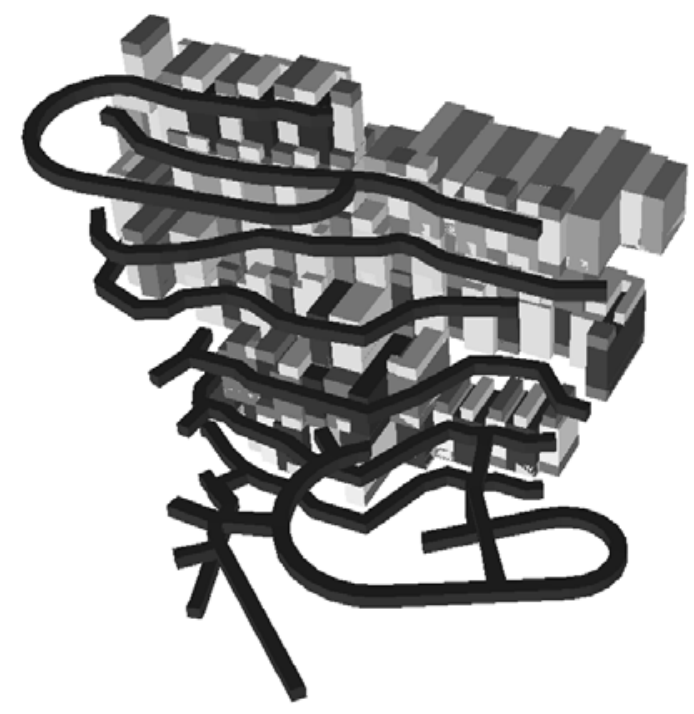

Figure 6 8P12S configuration

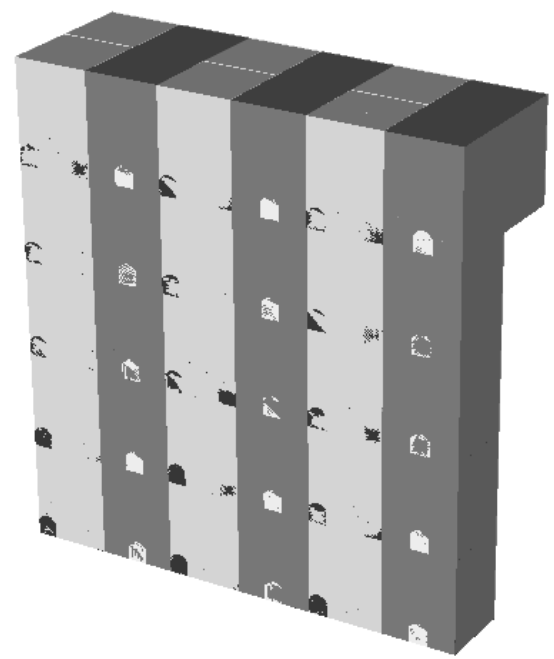

Figure 7 20P20S configuration

Two primary and two secondary stopes, each $25 \mathrm{~m}$ and $30 \mathrm{~m}$ (25P30S) (Figure 8) on strike respectively, and $80 \mathrm{~m}$ in height (or lift) have been used in the final design (Buckingham, 2007). Production drilling accuracy as well as support installation was important to reduce the damage to the hanging and footwall (Figure 9).

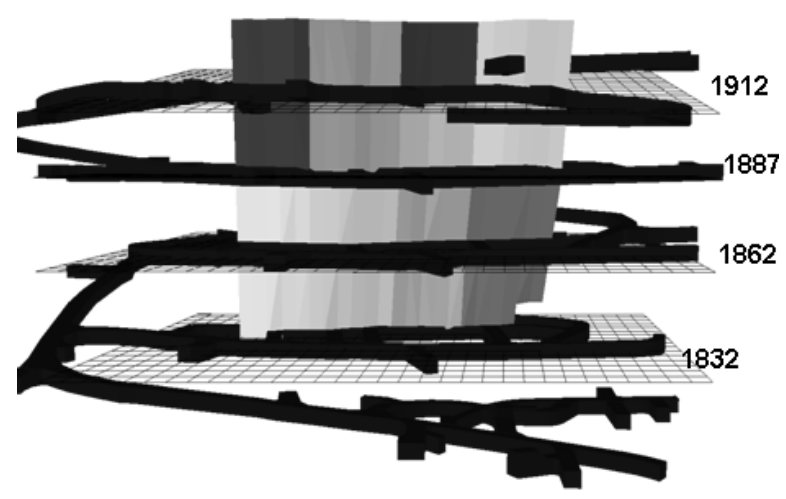

Figure $8 \quad 25 P 30 S$ stope configuration 

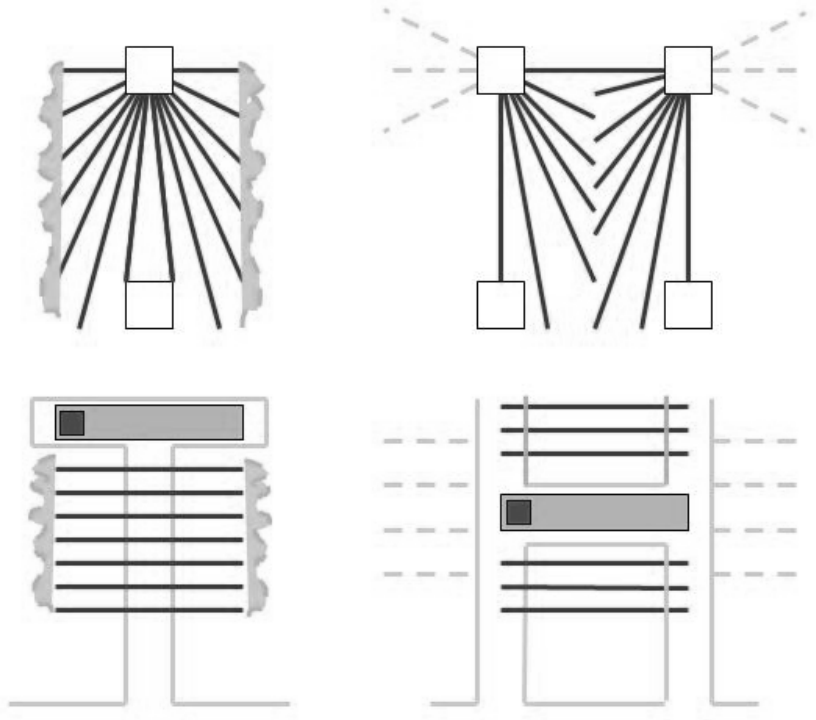

Figure 9 Cross section and plan view of two possible drill cross-cut positions

Perimeter cross-cuts, or dedicated hangingwall and footwall drives, was developed, and intermediate levels were spaced $25 \mathrm{~m}$ back (tunnel roof) to floor. This ensured that each stope has four access points on each level (Figure 9). Level and vertical pillar dimensions, or the proximity of excavations, were based on guidelines recommended by Guilfoyle (2007b), and was incorporated in the final layout (Figure 10).
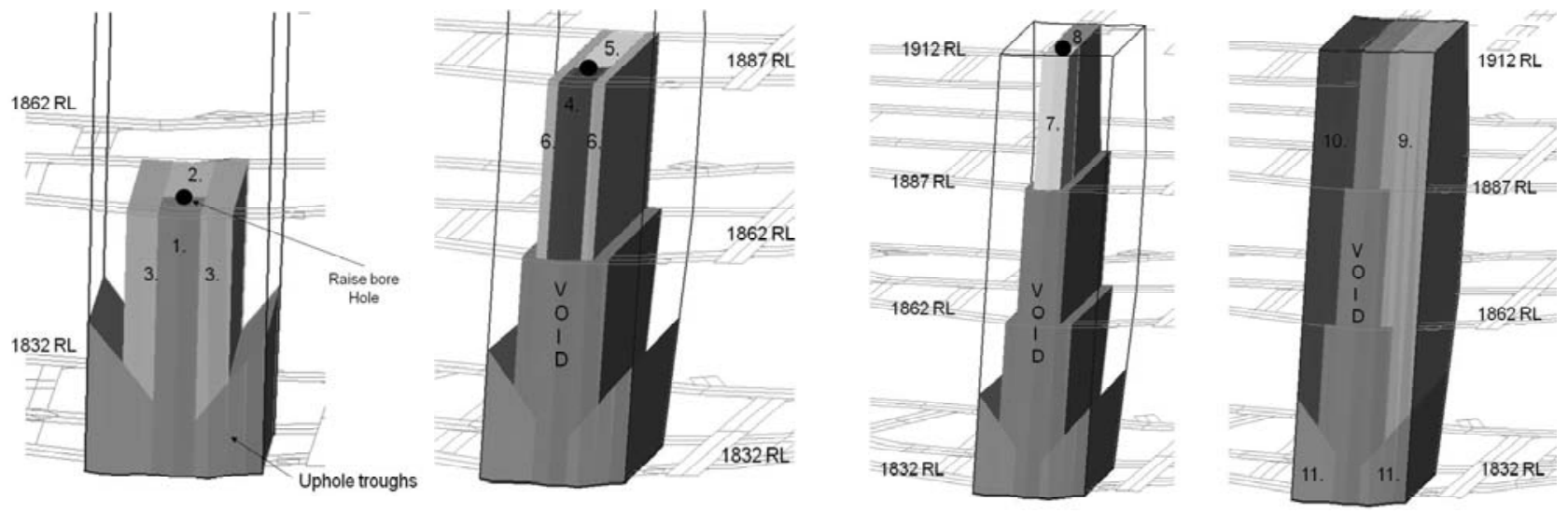

Figure 10 Primary stope extraction sequences (after Carroll, 2009)

\subsection{Support layout}

Off-reef tunnel support consisted of $50 \mathrm{~mm}$ fibrecrete and 20 tonne resin bolts (\$20 mm @ $2.4 \mathrm{~m})$. The original ore drives and crosscuts that will be mined through with the larger stopes were supported with fibrecrete and 12 tonne friction bolts $(\phi 46 \mathrm{~mm} @ 2.4 \mathrm{~m})$. Cable bolt support was only installed in the hangingwall and back of the stope. Stability analyses (Brockman, 2008a, 2008b) as well as numerical assessments (Nienaber, 2008b) have assisted to determine which walls should be supported. The typical cable bolt pattern is shown in Figure 11. Twin strand 25 tonne cable bolts ( $\$ 15.7$ mm @ 10 m) were used, with a bulb every $0.5 \mathrm{~m}$. Cable bolt rings were drilled $2.5 \mathrm{~m}$ apart and toes were $2.5 \mathrm{~m}$ apart to ensure a coherent $10 \mathrm{~m}$ deep $\times 10 \mathrm{~m}$ wide reinforced beam, vertically every $25 \mathrm{~m}$ (inter levels) along the $80 \mathrm{~m}$ hangingwall of the stope. Support in the stope back (stope roof) was $6 \mathrm{~m}$ cable bolts spaced $2.5 \mathrm{~m}$ apart in rings of three, along all exposed drives on the 1912 level. 


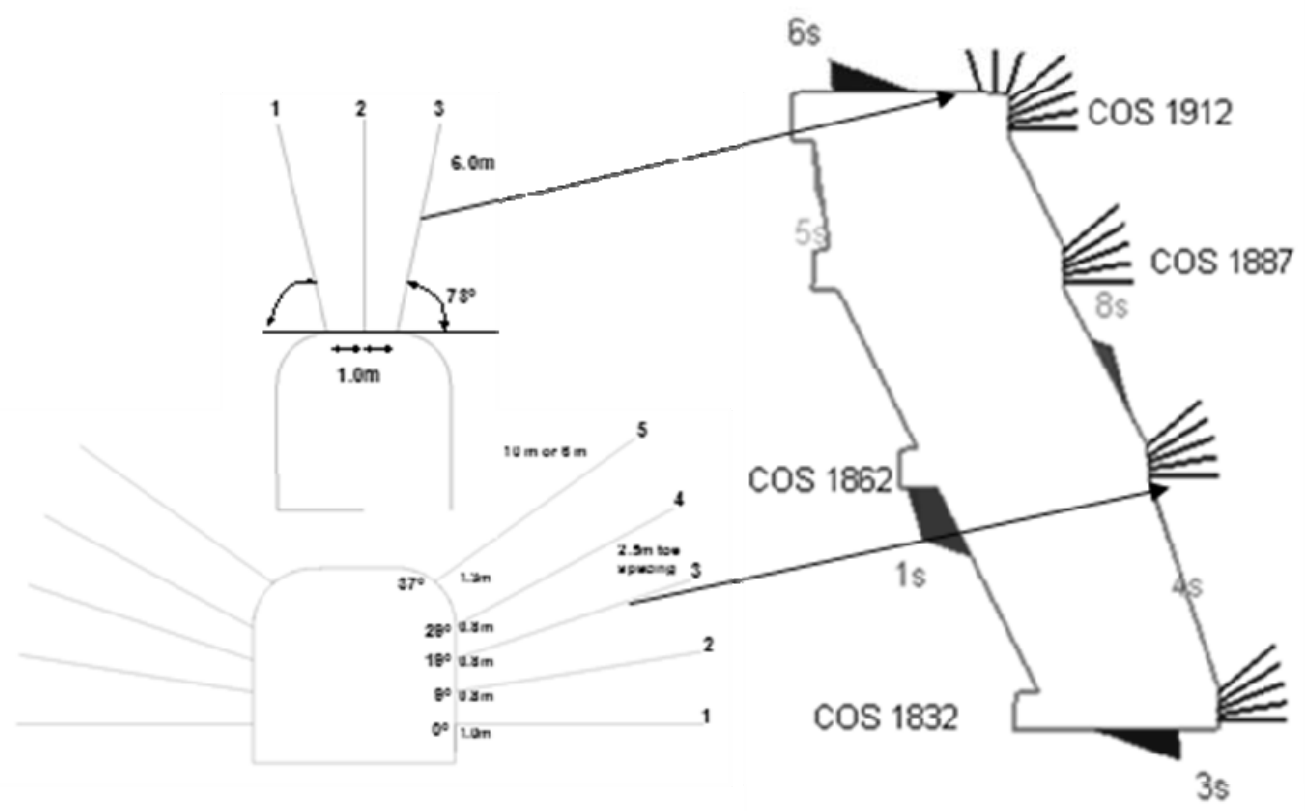

Figure 11 Left: ring patterns for backs and hangingwall; right: section view of $6 \mathrm{~m}$ and $10 \mathrm{~m}$ cable bolt rings in the backs and hangingwall

\section{$5 \quad$ Pre-mining assessment}

Kinematic and numerical analyses have been done and reported by various engineers. During the feasibility phase an evaluation between the secondary pillar stresses for the 8P12S and 20P20S configuration was done (Hamman, 2007c). It was found that the wider 20S pillars will be more stable. Although they will be subjected to higher stresses, the low strainburst index (Bamford, 2007) of the rock types in the pillar, indicate a low risk of pillar bursting.

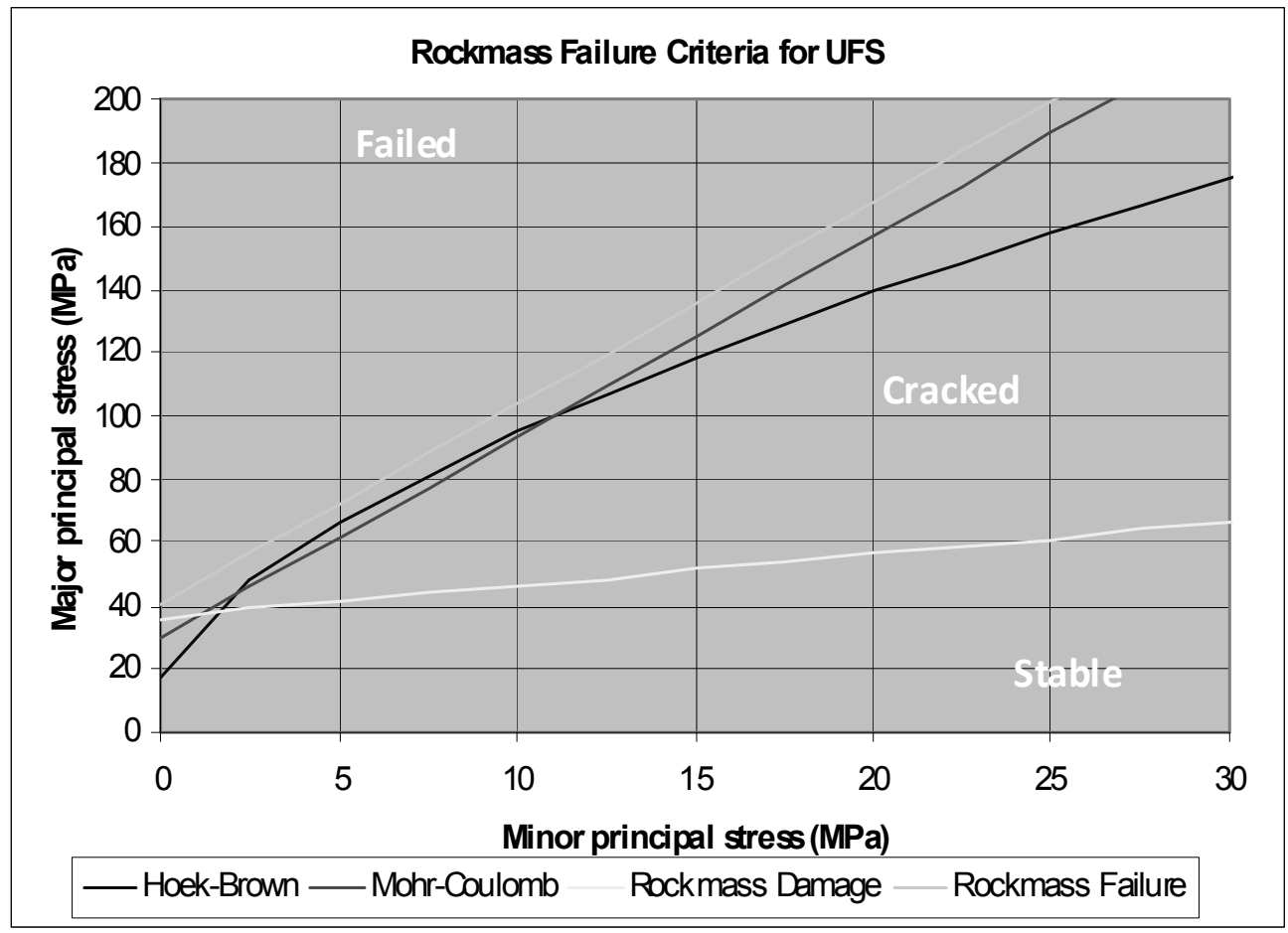

Figure 12 Rock mass failure criteria 
The failure criterions used in the above evaluation were based on the rock mass strength versus the applied principal stresses (Figure 12). The two criteria, rock mass failure (4) and rock mass damage (5), as proposed by Wiles et al. (2004) and further developed by Hamman (2007c) are:

$$
\sigma_{1}=40+6.12 \sigma_{3}
$$

Induced stresses that exceed this criterion will result in a failed rock mass incapable of supporting itself.

$$
\sigma_{1}-\sigma_{3}=36
$$

Induced stresses that exceed this criterion will cause damage or cracking of the rock mass.

A comparison has been done for the 20P20S configuration with 25P30S and for stope heights of $50 \mathrm{~m}$ and $75 \mathrm{~m}$ (Nienaber, 2008a). It was concluded that the $50 \mathrm{~m}$ versus $75 \mathrm{~m}$ lifts did not show major differences in induced stresses. For the primary and secondary stope lengths of 20P20S and 25P30S it was shown that the larger the secondary pillar the more stable it is (average pillar stresses will be lower).

Further analysis was done (Nienaber, 2009) to determine what the influence will be on nearby excavations during the extraction of the first two primary stopes (Figure 13). It was shown that the induced stress values on the inter levels and decline will not cause significant damage. The failure criterions (4 and 5) explained in Figure 12 was used to verify the onset of cracking and possible rock mass failure (Figure 14).

Peter O'Bryan and Associates (2008) endorsed the larger stopes proposed by SDGM and was of the opinion that the taller and wider (strike) secondary stopes will not be affected by increased stress since the rock mass is regarded as very competent.
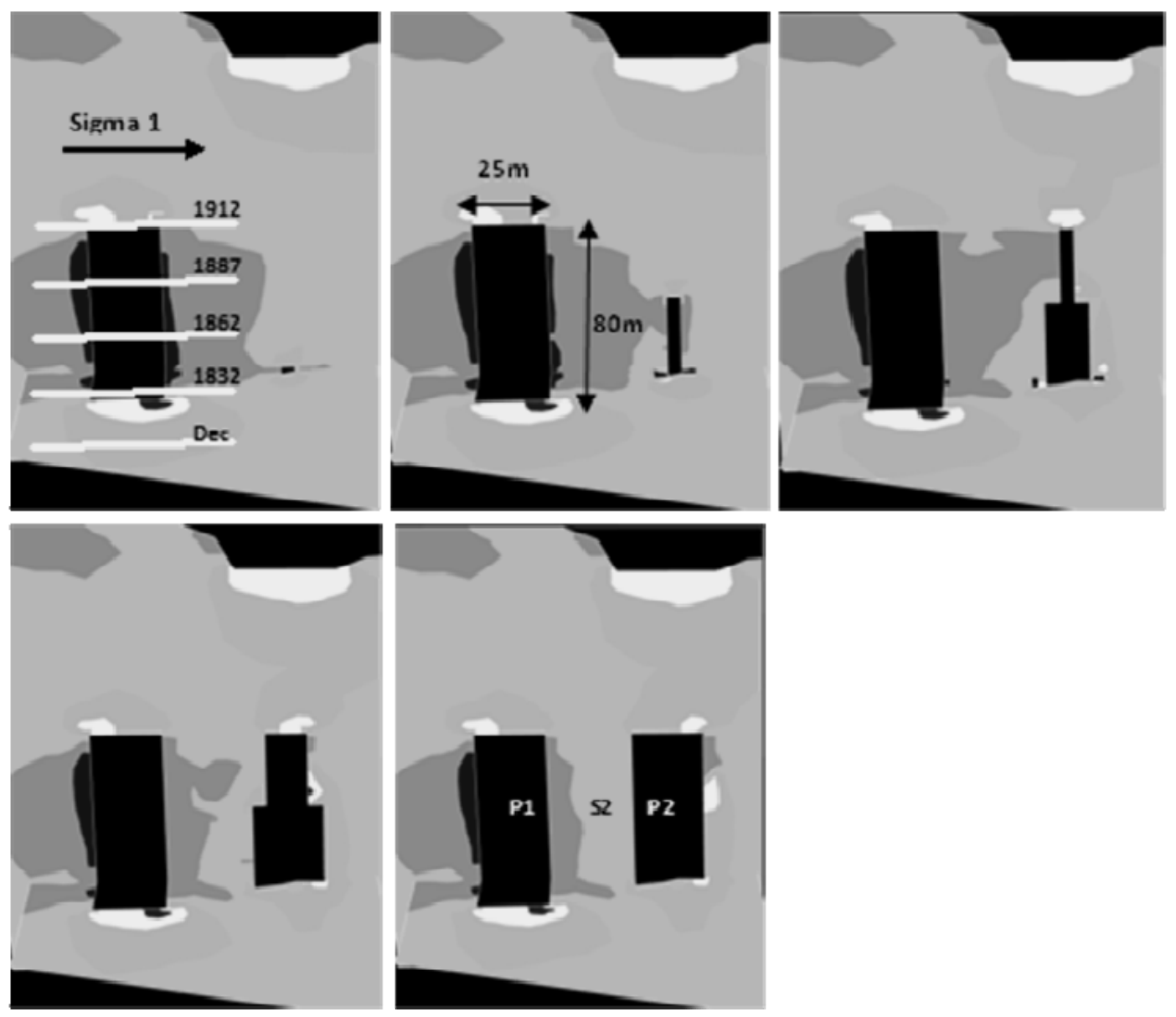

Figure 13 Sigma 1 stress values generated around the two primary stopes during the extraction sequence of Primary 2 


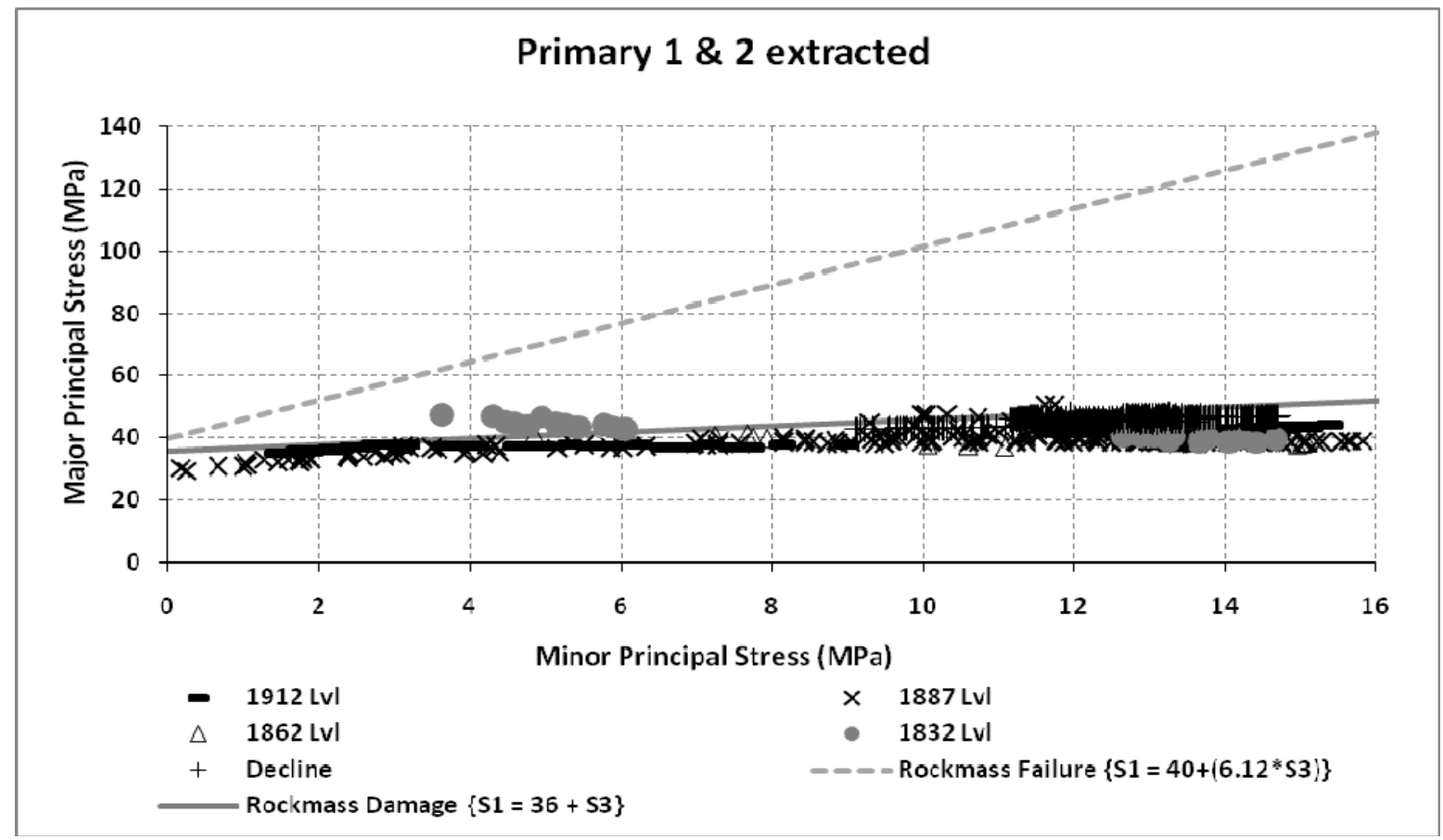

Figure 14 Rock mass failure criteria versus the major principal stresses at various positions around the two primary stopes

Pre-mining assessment on the Cosmo Primary 1 stope (Brockman, 2008b) included the following aspects: rock mass classification; stress orientation around the stope; kinematic analyses using Dips software; wedge analyses using Unwedge software; and stability analyses using the modified stability graph (Figure 15). It was concluded that only minor toppling failures may occur along the footwall and wedges of up to 400 tonnes (Unwedge) will have to be supported along the hangingwall. Joints sets used in Unwedge were set conservatively with a maximum persistence of $20 \mathrm{~m}$. Therefore in some sectors the support may be more than required.
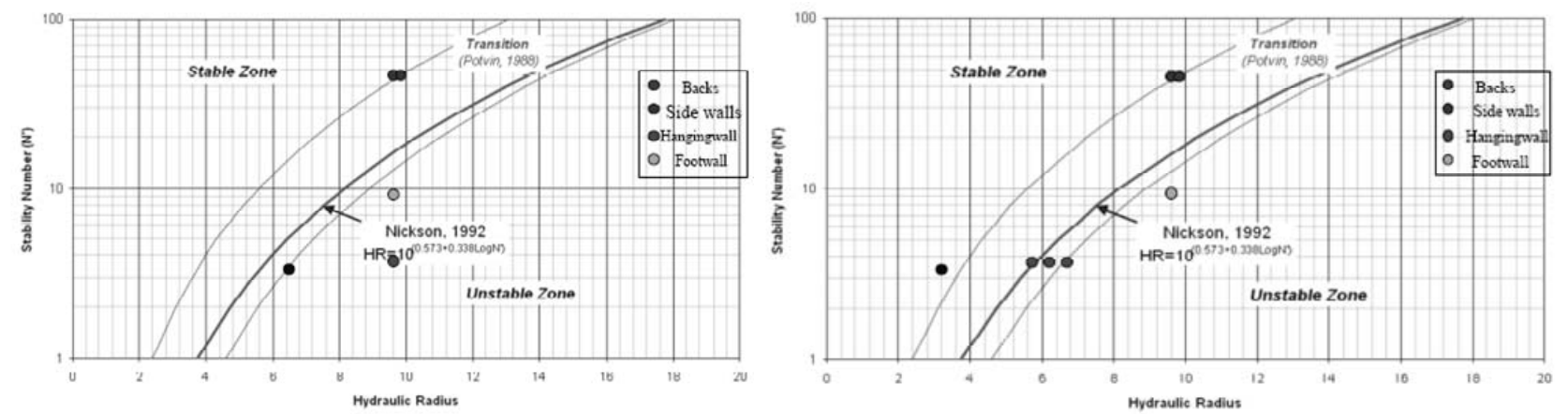

Figure 15 Pre-mining stability analyses showing a stable hangingwall when supported (right hand graph)

\section{$6 \quad$ Monitoring}

\subsection{Extensometer arrays}

Pre-mining assessment has shown that only limited toppling and small wedge failures may occur, it was nevertheless decided to gather as much information as possible from the first stope. The footwall as well as the north and south walls of all four stopes made it possible to install instrumentation on any level if required. However, the position of the access decline allowed limited installation positions to monitor the hangingwall of the stope. Multi-point rod-extensometers (MPBX) have been installed along three of the 
exposed walls of the Primary 1 stope, $25 \mathrm{~m}$ above the floor of the stope (Figure 16). Data recording was done manually pre and post-firing and then twice a week.

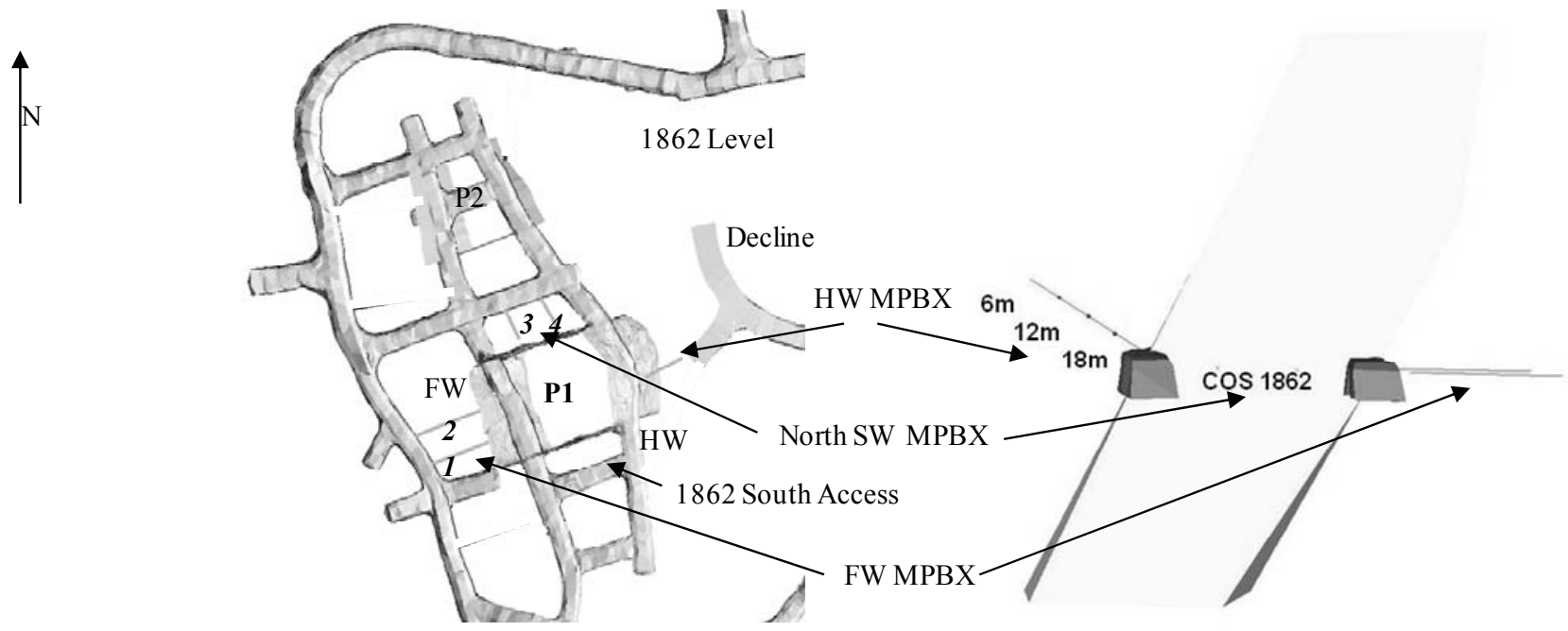
Figure $16 \begin{aligned} & \text { Plan and section view (south) of installed multi point bore hole extensometers around } \\ & \text { Primary } 1 \text { stope }\end{aligned}$

Each of the five MPBX's had three anchors points, one $2 \mathrm{~m}$ short of the designed stope wall and the remaining two spaced further back along the bore hole. This was to determine the depth of deformation around the stope. The 1862 south access drive was not developed at the time of mining since it was only required for the first secondary stope, hence no installation of extensometers were possible in the south sidewall.

During the extraction the $165 \mathrm{kt}$ Primary 1 stope the extensometers installed in the hangingwall and footwall did not show any significant movements. This was confirmed with the post-mining assessment (Brockman, 2009) where the cavity monitoring survey (CMS) results were compared to the designed stope shape. However, the north sidewall arrays (3 and 4 in Figure 16) did show movement towards the south, or into the open void. It was reported (Nienaber, 2009) that the massive firings in Primary 1 stope and even later in Primary 2 stope, $35 \mathrm{~m}$ away to the north, was directly related to the movements recorded (Figure 17). The 1st primary firings resulted in a step change followed by a long period of small changes. A much larger step change was seen when the firing in the second primary was started. Anchor \#3-8 $\mathrm{m}$ was most probably damaged by blasting and show a negative trend which was not mirrored by its neighbour \#4-8 m.

Underground observations in the immediate vicinity of the collars of the extensometer holes, and the surrounding rock mass in the $186275 \mathrm{Y}$ access drive did not reveal signs of rock deformation or induced stress during the extraction of Primary 1. Minor cracking in the fibrecrete was observed towards the end of the extraction of Primary 2 along the same drive. 

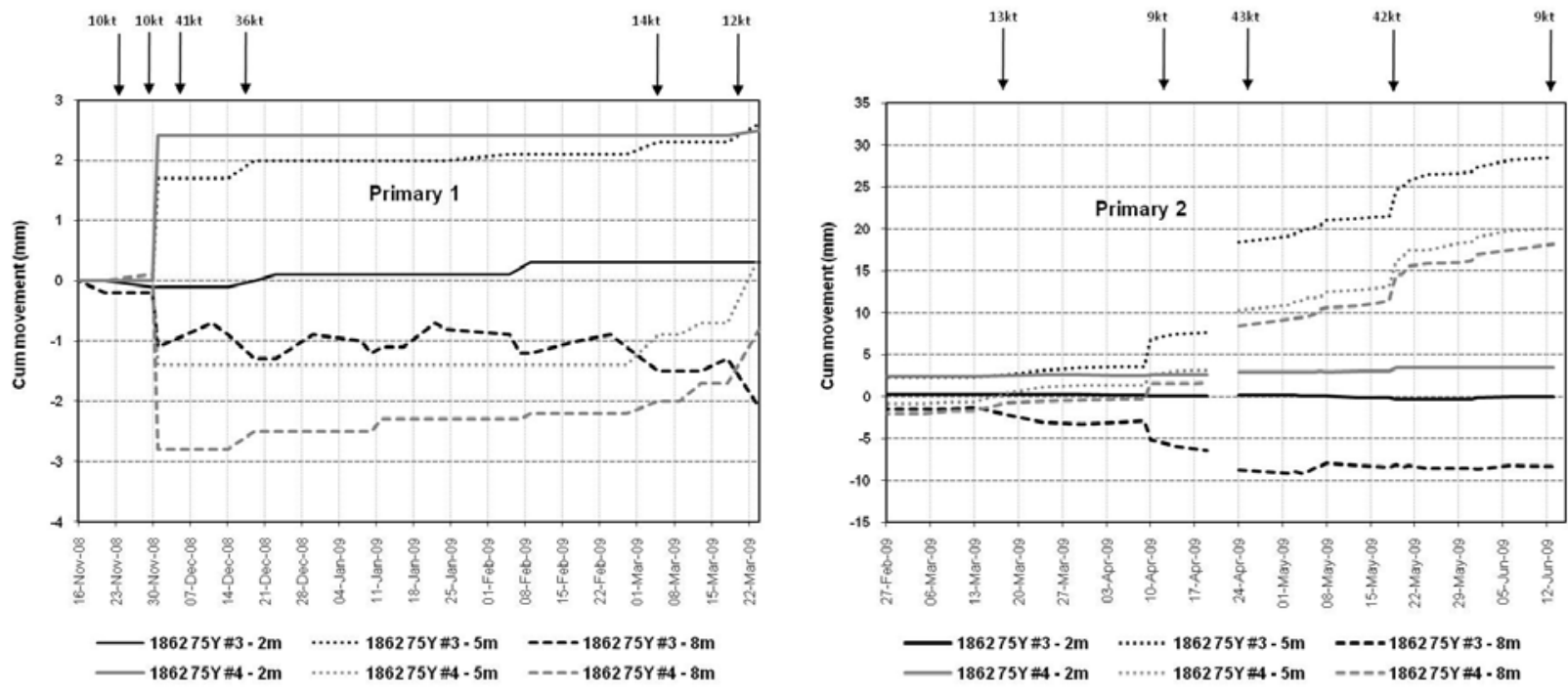

Figure 17 Ground movement recorded by MPBX's 3 and 4 installed in the north wall of Primary 1 in $186275 Y$ drive. The bottom figures show the actual position of the arrays in relation to the CMS profile of the void, and the position of Primary 1 and Primary 2

Significant cracking and failure of the fibrecrete was observed in the $183275 \mathrm{Y}$ drive, located $25 \mathrm{~m}$ directly below the extensometer positions. However this pillar, between the $75 \mathrm{Y}$ drive and the stope void was much thinner and has fractured due the increased stress loading (Figure 18). This was confirmed during the drilling of reinforcing steel for the paste fill barricades.

\subsection{Cavity monitoring survey}

Reconciliation of the designed versus as-built stope void was done using CMS results. The main outcome was to estimate the dilution, from an economic perspective, and to verify if the installed support was effective in limiting dilution.

It was reported (Brockman, 2009) that the overall stope appears to be stable, as evident from observations, limited over break, and seismic and extensometer monitoring. Overall an extra $\sim 1,400 \mathrm{~m}^{3}$ was measured with the CMS compared to the design, resulting in only $2.3 \%$ dilution, excluding under break on the floor of the stope. Failure mechanisms were toppling failure in the footwall and small wedge failures in the hangingwall. The stability graph shows that rock mass has been under-rated and hence a shift in the curve to the right was proposed (Figure 19).
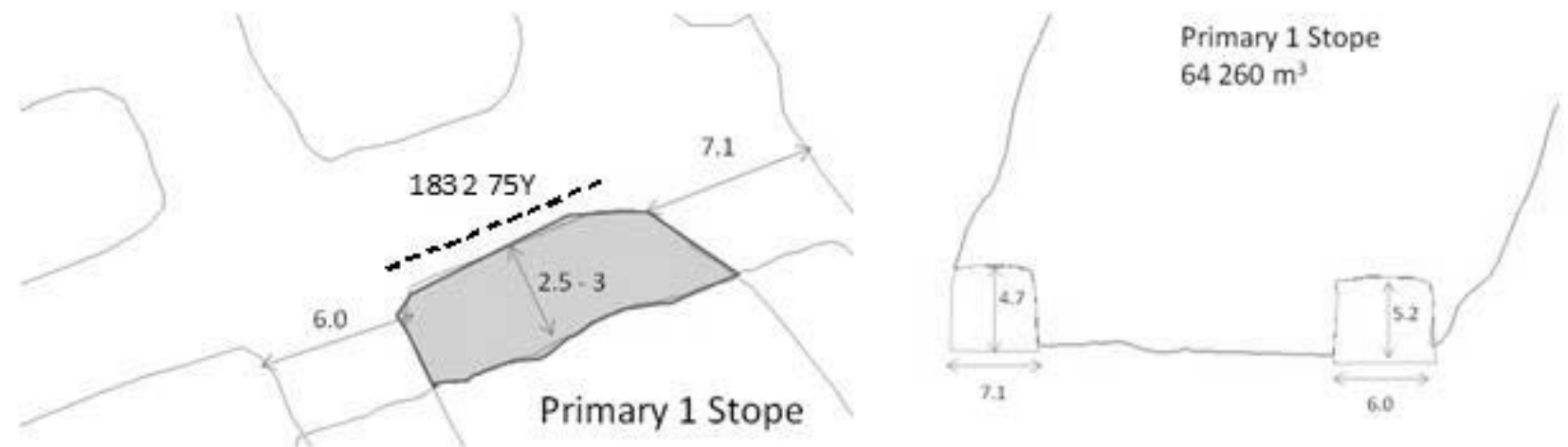

Figure 18 Plan and section east-west (view south) of Cos 183272 Y drive showing fibrecrete damage on the shoulder of the drive 


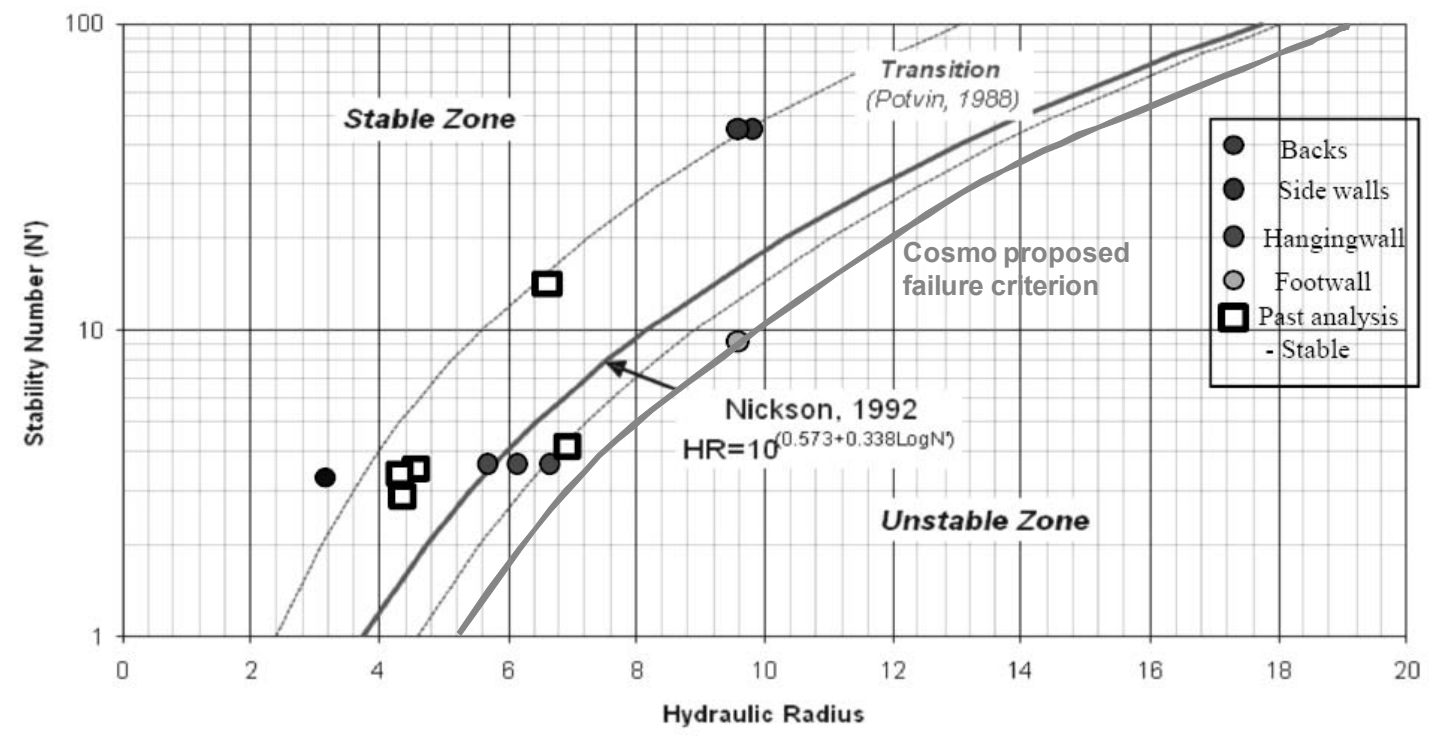

Figure 19 Post mining stability assessment and proposed failure criterion for the Cosmo orebody

\section{Conclusion}

The process followed has assisted to gain knowledge and experience which was critical to confidently optimise designs. This has resulted in every design iteration validating the previous design.

\section{Acknowledgement}

The teamwork of the technical team at SDGM as well the permission from AngloGold Ashanti Australia to publish the paper is greatly acknowledged.

\section{References}

Bamford, W. (2007) Strain Burst Testing, Laboratory report on rock testing for Sunrise Dam Gold Mine, Department of Civil and Environmental Engineering, The University of Melbourne, Victoria, Australia.

Barton, N. Lien, R. \& Lunde, J. 1974. Engineering classification of rock masses for the design of tunnel support, Rock Mechanics. 6:4:189-236 http://en.wikipedia.org/wiki/Rock_Mass_Rating_system\#Rock_mass_rating_system

Brockman, M. (2009) Cosmo stope reconciliation geotechnical analysis $1832 \mathrm{E}$, Internal report to SDḠM.

Brockman, M. (2008a) Cosmo stope pre-mining geotechnical assessment $1862 \mathrm{H}$ stope, Internal report to SDGM.

Brockman, M. (2008b) Cosmo stope pre-mining geotechnical assessment $1832 \mathrm{E}$ stope, Internal report to SDGM.

Buckingham, A. (2007) Update on Cosmo Mine Sequence and Layout, Internal memorandum to SDGM.

Carroll, E. (2009) Cosmo 1832 E and 1832 C presentation, Presentation at the SDGM GRP 2009.

Cowan, M. (2006) Cosmo initial geotechnical study, Internal report to SDGM.

Guilfoyle, K. (2007a) Cosmo planning initial review 300607, Technical report to SDGM.

Guilfoyle, K. (2007b) Cosmo planning design concepts 050907, Technical report to SDGM.

Guilfoyle, K. (2007c) Cosmo mine planning strategies 231107, Technical report to SDGM.

Hamman, E. (2007a) Monte Carlo simulation Cosmo, Internal Excel spreadsheet for SDGM.

Hamman, E. (2007b) Underground evaluation Cosmo, Internal Excel spreadsheet for SDGM.

Hamman, E. (2007c) Evaluation - Cosmo 20P20S vs 8P12S stopes, Internal report to SDGM.

Hamman, E. (2007d) Underground feasibility study - geotechnical considerations, Internal technical report to AngloGold Ashanti Australia.

ISSP (2009) Monthly seismic report 16 May to 15 June 2009, ISSP International Seismic Services technical report to SDGM.

Litterbach, N. (2008) Stress measurement in the GQ Link drive, Technical Report to SDGM.

Nienaber, L. (2009) 180609 COS Primary 1 stope - stability of the 1862 north pillar, Internal memorandum to SDGM.

Nienaber, L. (2008a) Cosmo Comparing stope sizes, Internal memorandum to SDGM.

Nienaber, L. (2008b) Cosmo - interaction between planned stopes and excavations, Internal memorandum to SDGM.

Nugus, M.J. and Biggam, J. (2007) Geology of Sunrise Dam Gold Mine, Internal report to SDGM. 
Peter O’Bryan and Associates (2008) Review of the proposed Cosmo Mining Strategy, Technical Report 0402 to SDGM.

Rocscience user manual for UNWEDGE and DIPS.

Villaescusa, E., Windsor, C.R. and Machuca, L. (2006) Stress measurements from oriented core using the Acoustic Emission method for Sunrise Dam Gold Mine, The Western Australian School of Mines, Curtin University of Technology, Kalgoorlie, Western Australia.

Wiles, T., Villaescusa, E. and Windsor, C.R. (2004) Rock reinforcement design for overstressed rock using threedimensional numerical modelling, in Proceedings Fifth International Symposium on Ground Support, Ground Support in Mining and Underground Construction, E. Villaescusa and Y. Potvin (eds), 28-30 September 2004, Perth, Australia, A.A. Balkema Publishers, London, pp. 483-489. 
